\title{
An Appraisal of Road Condition Effect on Rural Transportation in Sekyere Central District of the Ashanti Region of Ghana
}

\author{
Adewunmi Taiwo ${ }^{1}$, Francis Kumi ${ }^{2}$ \\ ${ }^{1}$ Department of Agricultural Engineering, Ladoke Akintola University of Technology, Ogbomoso, Nigeria \\ ${ }^{2}$ Department of Agricultural Engineering, University of Cape Coast, Cape Coast, Ghana \\ Email: padetaiwo@yahoo.com, fekkumi@yahoo.com
}

Received August 9, 2013; revised September 11, 2013; accepted September 28, 2013

Copyright (C) 2013 Adewunmi Taiwo, Francis Kumi. This is an open access article distributed under the Creative Commons Attribution License, which permits unrestricted use, distribution, and reproduction in any medium, provided the original work is properly cited.

\begin{abstract}
The objective of this study was to assess the condition of the road network within the district with a view to find out if and how they affect the transportation costs. Four sets of primary and secondary data on the district's road surface types, road condition mix, cost of transportation of farm produce and humans on the road network were collected, collated and subjected to statistical analysis using a Completely Randomized Design. The results indicated that the road conditions had high significant effects on the transportation costs of both human and agricultural produce. The road network of the district consists of 21 roads with a total length of 176.6 kilometers out of which 8 were classified as poor, 7 as fair and only 6 as good. The highest agricultural produce transportation cost of $\mathrm{GH} \notin 1.46$ per tonne-kilometer was obtained from 3 of the poor roads while the lowest cost of GH $\varnothing 0.86$ per tonne-kilometer was obtained from only 1 of the 6 good roads. The highest passenger transportation cost of GH $\varnothing 0.3$ per passenger kilometer was obtained for 1 of the 8 poor roads while the lowest cost of $\mathrm{GH} \notin 0.1$ per passenger kilometer was obtained for all the 6 good roads and 4 of the fair roads. In conclusion, transportation cost of passengers on the poor and fair roads was $2-3$ times as high as the cost of transportation on the good roads. Transportation cost of agricultural produce on the poor roads was $70 \%$ higher than it was on the good roads.
\end{abstract}

Keywords: Macadam; Passenger-Kilometer; Tonne-Kilometer; Rural Transportation; Farm Produce

\section{Introduction}

Transportation can be defined as the movement of persons, goods and information, by any means and for any purpose, from one place to another (origin to destination). It normally involves two complementary components namely: transportation infrastructure, also called "fixed plant", and transportation services, or "mobile equipment". Neither component can be productive without the support of the other [1]. For food products, the transport function adds "i.e. places utility" on products through their transfer from production areas (where there are no opportunities for surpluses to meet the needs of people), to urban areas (where they become accessible to interested consumers). The simple transfer from one place to another adds value to production [2].

An efficient transportation system is necessary for the development and facilitation of economic growth because it fulfills the following functions: 1) provision of physical access to resources and markets, thus favouring effective marketing of agricultural products, industrial specialization and simultaneous expansion of production and employment; 2) helping to open up new markets, promoting domestic and international trade; 3 ) reduction of transaction costs (inputs and products), leading to economies of scale and specialization due to improvement in transportation and 4) contribution to economic diversification, thus making a country less vulnerable to possible adversity as a result of continuous investment in the sector.

Improved transportation can also help to alleviate poverty by facilitating economic growth, thus backstopping specific interventions and fostering rural development.

Transportation is highly influential in the overall development of the food chain. The existence of accessible, acceptable, efficient transportation system is a pre-condition for linking remote farm areas located far from 
consumer centers with the agricultural production process.

Proper management is the key to maintaining the quality of perishable food products from harvest to the final consumer, because a food product has to be transported from farm-gate to the market. Farmers, worldwide, employ a wide range of various means for transporting their products to the markets, some of which include: horses, boats, small vehicles, trucks, buses etc. The chosen means of transportation requires serious consideration because unnecessary high transportation costs can result in serious losses and subsequent bankruptcy. Wherever and whenever a selected means of transportation in neither timely nor cost effective, a substantial chunk of the profit could easily be wiped out due to spoilage and high cost. The main impact of transportation on the quality of agricultural products concerns itself with the widespread lack of awareness of the correct food management, packing and transport practices for market by farmers who are often unschooled in the minimum technical needs of food handling and packing [1].

Agriculture in most parts of the world takes place in the rural areas since these are the places where large tracts of land can easily be obtained and also where agricultural activities will not create problems for inhabitants. This implies that efficient transportation services should be made readily available to farmers so as to prevent unnecessary loss due to delay in moving produce from the farm to the market centers. Transportation can be made readily available and accessible to the farmers through the provision of good access roads, provision of trucks and their spare parts in the right quantities for their regular repair and maintenance.

Unfortunately however, rural transportation is a serious problem in most developing countries of the world, including Ghana, because most of her rural communities lack easy access to efficient transportation systems. It is also generally recognized that the transport operating costs, are higher on rough roads than on good quality and well-maintained asphalt-surfaced roads and that this is often reflected in the passenger fares and freight tariffs. This indicates that there is substantial scope for establishing the need for improving the efficiency of transport operations in many developing countries.

As the improved national road network extends further throughout the country, the rural economy becomes more dependent on it. However, sustainability of this network is an issue as it is deteriorating because of the lack of adequate road maintenance combined with rapidly growing traffic, poor road maintenance standards, in addition to design and construction deficiencies. Inadequate road maintenance is primarily often due to serious shortfall in the provision of financial resources as and when due general poor general financial management, planning which precedes poor implementation of road maintenance strategies in addition to weak technical capacity of road maintenance agencies and local contractors [3].

In Ghana, studies have shown that, at National level, the agricultural sector employs, at least, 55 percent of the working population, which rises to above $75 \%$ at the rural community level. More than $35 \%$ of the Nation's Gross Domestic Product (GDP) comes from agriculture [4]. This pattern is not much different from what obtains in most other economies in the Sub-Saharan Africa [5].

It is extremely difficult for most farmers who live and farm in the Sekyere Central District of the Ashanti Region of Ghana to gain access to vehicles with which to transport their farm produce to market centres on time because big truck owners and drivers have abandoned most of the roads to commercial motorcycle operators due to district wide poor road conditions. In effect, the socio-economic wellbeing of the community members are seriously affected due to high cost of agricultural inputs and depressed prices of farm produce.

It is in pursuance of solution to these problems that the general objective of this study was to assess the condition of the road network within the district with a view to find out if and how they affect the transportation costs. The specific objectives were to identify the feeder roads within the district road network and classify into three groups according to their appraised conditions; investigate the transportation cost of human and agricultural produce on each road and establish the level of significance of the effects of their conditions on the transportation costs of human and agricultural produce moved on them.

\section{Materials and Methods}

\subsection{Study Area and Data Collection}

The study area was the Sekyere Central District carved out of the former Sekyere West District of the Ashanti Region of Ghana in February, 2008. The district is located within longitudes $0.05^{\circ} \mathrm{E}$ and $1.30^{\circ} \mathrm{W}$ and latitudes $6.55^{\circ} \mathrm{S}$ and $7.30^{\circ} \mathrm{N}$. It is located in the northern part of Ashanti Region and shares boundaries with five other districts namely: Mampong Municipality, Ejura-Sekyeredumasi, Amatin-Atebubu, Sekyere Afram Plains and Sekyere East Districts. The district whose capital is Nsuta has an estimated population of 75,969 with intercensual growth rate of $1.4 \%$ per annum, according to the 2008 National census. The rural population is about $63.7 \%$ whilst the urban population is about $36.3 \%[6,7]$.

A baseline survey was conducted by collecting secondary data on the District road network from the District offices of the Department of Feeder Roads (DFR) and the Ministry of Food and Agriculture (MoFA). Data on the features, length, and surface type of each road were obtained from DFR while data on mass and type of agri- 
cultural produce transported on each road annually were obtained from MoFA. Data on tariffs paid for transportation of agricultural produce and fares paid for the transportation of humans on each road of the district road network were obtained from the Ghana Private Road Transport Union (GPRTU) of the Trade Union Congress (TUC), Nsuta branch. These tariffs and fares were corroborated by focus group discussion held with some selected farmers' representatives and community leaders within the district.

\subsection{Primary Data Collection}

Primary data on road conditions were collected for each road by visiting and making on-the-spot observation. The three types of road surfaces in the district are Macadam, Bitumen/Asphalt and Earth surface. The road conditions were classified into three groups for the purpose of this study as: good roads, fair roads and poor roads. These classifications based on the presence of surface defects such as pot holes and undulations as well as the average speed at which drivers can move on them with a reasonable margin of safety. Those roads that had unclogged culverts and channels, smooth Macadam/Bitumen/Asphalt paved surface and shoulders without pot holes throughout their lengths thus making it possible for drivers to drive on them at the rated speed limit were classified as good roads; those roads that storm drains, shoulders and channels on both sides with Asphalt/Macadam/ Bitumen surface without pot holes were classified as good roads. Those roads that had some clogged culverts and channels, Macadam/Bitumen/Asphalt paved surface and shoulders with some pot holes in $50 \%$ or less of their lengths thus making it impossible for drivers to drive on them at the rated speed limit throughout their lengths were classified as fair roads. Those roads that had clogged or no culverts and channels, earth and undulating surface and without shoulders thus making it impossible for drivers to drive on them at a reasonable speed throughout their lengths were classified as bad roads.

\subsection{Data Processing and Analysis}

The secondary data collected on tariffs paid for transportation of agricultural produce and fares paid for the transportation of humans on each road of the district road network were converted into Agricultural Produce Transport Tariff in GH $\phi$ per tonne-kilometer and Passenger Transport Fare in GH $\not$ per passenger-kilometer respectively. The transportation tariffs paid for the transportation of agricultural produce were converted to those moved by a 10-tonne truck equivalent. This is in accordance with the practice among the GPRTU drivers who will never move their loaded truck unless loaded to capacity and sometimes even beyond capacity.
These data were combined with those collected on road mix, their conditions and length and combined for presentation in a table each for passenger and agricultural produce transportation.

In order to establish the level of significance of the effect of the road conditions on the Tariff paid for the transportation of agricultural produce and the fare paid for the transportation of humans on the district network of feeder roads, the data on agricultural produce and human transportation were collated and subjected to analysis of variance using a Completely Randomized Design (CRD).

\section{Results and Discussion}

\subsection{Identification and Classification of Feeder Roads within the District Road Network}

The results in Tables $\mathbf{1}$ and $\mathbf{2}$ show that Sekyere Central District had 21 feeder roads in her road network with a cumulative length of 176.6 kilometers out of which 8 of them with a total length of 52.8 kilometers were classified as poor. Only 6 of them with a total length of 54.4 kilometers were classified as good while the remaining 7 with a total length of 67.9 kilometers were classified as fair. The roads classified as poor had neither culverts nor bridges throughout their lengths, resulting in rivers and streams flowing across the road surfaces during the raining seasons. At this time most truck owners and drivers avoid plying these routes; a few of them that try to usually get their vehicles stocked in the waterlogged road Surfaces and sometimes in the water bodies resulting in incalculable delay and serious mechanical problems.

Even when they manage to transport their produce on these poor roads, they are forced to sell at elevated prices, the implication of which will result in uncompetitive market prices of their produce. This result above is in line with a study carried out in the Ashanti Region, Ghana by [8] who reported that transportation cost accounts for $5 \%$ and $15 \%$ price difference in maize and yam respectively whenever they are transported from low price market centres to high price market centres.

\subsection{Cost of Human Transportation on the District Road Network}

Although the cost of travelling on a kilometer length of good road within the District by a passenger was only $\mathrm{GH} \phi 0.1$, double, and sometimes, three times this value was paid by a passenger (i.e. GH $\varnothing 0.20$ or $\mathrm{GH} \varnothing 0.30$ ) travelling on poor and fair roads. This has serious negative implications on passenger transportation around the district since only approximately $29 \%$ of the roads in the District are in good condition. The remaining $71 \%$ that are either poor or fair do not only affect the socio-economic lives of the people, they also make it extremely 
Table 1. Condition of Sekyere central district road network and transport fares (GHc/passenger-kilometer).

\begin{tabular}{|c|c|c|c|c|}
\hline Roads & Condition & Length $(\mathrm{km})$ & Passenger Transpt. Fare, GH $\varnothing$ & $\begin{array}{l}\text { Passenger Transport. Fare, } \\
\text { GH } \phi \text { passenger-kilometer }\end{array}$ \\
\hline Hwidem-Nsuta & Good & 6 & 0.60 & 0.1 \\
\hline KruwiJn-Kruwi & Good & 2 & 0.20 & 0.1 \\
\hline Mpentuase-Achiase & Poor & 2.5 & 0.50 & 0.2 \\
\hline Achiase-Amangoase & Poor & 3.5 & 0.80 & 0.2 \\
\hline Kwamang-Jeduako & Good & 16.4 & 1.70 & 0.1 \\
\hline Ankamadua-Nkudwoa & Fair & 7.0 & 0.70 & 0.1 \\
\hline Nkodwoa-AframsoII & Poor & 10.5 & 2.0 & 0.2 \\
\hline Aframso II-Odumase & Poor & 8.0 & 1.50 & 0.2 \\
\hline KwamangJn-Ankamadoa & Good & 15 & 1.50 & 0.1 \\
\hline Ankamadua-Jeduako & Fair & 18 & 2.0 & 0.1 \\
\hline Atonsu-Dida & Poor & 9 & 1.80 & 0.2 \\
\hline Jeduako-Birem & Fair & 33.6 & 4.0 & 0.1 \\
\hline Kwamang-Kumawu & Good & 9 & 0.90 & 0.1 \\
\hline Daamang-Jetiase In & Poor & 1.8 & 0.50 & 0.3 \\
\hline Mampong-Jetiase & Fair & 6 & 0.80 & 0.1 \\
\hline Birem-Anyinofi & Poor & 12.5 & 2.50 & 0.2 \\
\hline Beposo-Wioso & Good & 6 & 0.60 & 0.1 \\
\hline Atwea-Abusua & Fair & 1.8 & 0.40 & 0.2 \\
\hline Atwea-Adutwam & Fair & 1.5 & 0.30 & 0.2 \\
\hline Juanso-Nkubemu & Poor & 5 & 1.0 & 0.2 \\
\hline Ankamadua-Fawoma & Fair & 1.5 & 0.30 & 0.2 \\
\hline
\end{tabular}

difficult, if not impossible, for them to gain access to educational and health care facilities. The lack of access to educational facilities suffered by the people also extends to lack of access to information in terms of extension services, which has immediate effect on the development of agricultural activities within these areas. This finding is very much in line with the result obtained from a study on the impact of poor road condition on transport fare by [9]. It was concluded in the study that truck charges will increase by as much as $16 \%$ for trip that is more than $50 \mathrm{~km}$ for every $50 \%$ increase in the roughness; the value of increase in truck charges is almost double for a pick-up truck [10-13].

\subsection{Cost of Transportation of Farm Produce on the District Road Network}

From Table 2, the cost of transporting a tonne of agricultural produce on a kilometer length of good road within the district was $\mathrm{GH} \varnothing 0.86$ per tonne-kilometer and was
$\mathrm{GH} \varnothing 1.50$ per tonne-kilometer poor roads with the amount paid for fair roads lying somewhere between the two. These figures signify that the condition of the road surface has serious effect on the cost of transporting agricultural produce from the farm to the city-processing centre. Whenever the cost of transportation of farm produce from the farm to market centres are high, farmers are forced to leave their produce to rot on the farm after harvesting the quantity needed for their families or sold below cost of production to middle men who manage to come over to their farm sites to take undue advantage of them.

\subsection{Effect of Road Condition on Passenger Transportation Cost on the District Road Network}

When the data collected on the passenger transportation cost on the district road network were subjected to analysis of variance, the road conditions were found to have highly significant effect on the cost because they were sig- 
Table 2. Transport tariffs for movement of agricultural produce by truck on the district road network.

\begin{tabular}{|c|c|c|c|}
\hline Roads & Condition & Distance $(\mathrm{km})$ & Transportation Tariff for Truck Load $(\mathrm{GH} \phi)$ \\
\hline Hwidem-Nsuta & Good & 6 & 53 \\
\hline KruwiJn-kruwi & Good & 2 & 18 \\
\hline Mpentuase-Achiase & Poor & 2.5 & 36 \\
\hline Achiase-Amangoase & Poor & 3.5 & 51 \\
\hline Kwamang-Jeduako & Good & 16.4 & 144 \\
\hline Ankamadua-Nkudwoa & Fair & 7.0 & 82 \\
\hline Nkodwoa-Aframso II & Poor & 10.5 & 153 \\
\hline Aframso II-Odumase & Poor & 8.0 & 117 \\
\hline KwamangJn-Ankamadoa & Good & 15 & 130 \\
\hline Ankamadua-Jeduako & Fair & 18 & 210 \\
\hline Atonsu-Dida & Poor & 9 & 130 \\
\hline Jeduako-Birem & Fair & 33.6 & 390 \\
\hline Kwamang-Kumawu & Good & 9 & 80 \\
\hline Daamang-Jetiase In & Poor & 1.8 & 26 \\
\hline Mampong-Jetiase & Fair & 6 & 70 \\
\hline Birem-Anyinofi & Poor & 12.5 & 180 \\
\hline Beposo-Wioso & Good & 6 & 53 \\
\hline Atwea-Abusua & Fair & 1.8 & 21 \\
\hline Atwea-Adutwam & Fair & 1.5 & 18 \\
\hline Juanso-Nkubemu & Poor & 5 & $\mathrm{GH} \varnothing 70$ \\
\hline Ankamadua-Fawoma & Fair & 1.5 & $\mathrm{GH} \notin 18$ \\
\hline
\end{tabular}

nificant at both 5.0 and 1.0\% level of confidence (Table 3).

\subsection{Effect of Road Condition on Transportation Cost of Agricultural Produce on the District Road Network}

When the data on the cost of transportation of Agricultural produce on the district road network were similarly subjected to analysis of variance, the results obtained in Table 4 show that the road conditions also had highly significant effect on the transportation cost of farm produce on the district road network due to the same reason adduced in the case of passenger transportation ANOVA results.

\section{Conclusions}

The relationship between road conditions in Ghana and the transportation cost of passengers and farm produce to market centres using Sekyere Central District of Ashanti Region as a case study has been established in this study. The study revealed that $64.59 \%$ (or $113.10 \mathrm{~km}$ ) of the district road network had earth surface with $32.84 \%$ (or $57.50 \mathrm{~km}$ ) having Macadam surface while only $3.43 \%$ (or $6.00 \mathrm{~km}$ ) had asphalt surface. In addition, only $28.33 \%$ (or $49.60 \mathrm{~km}$ ) of the road network could be classified as being good while $32.21 \%$ (or $56.40 \mathrm{~km}$ ) and $40.43 \%$ (or $70.80 \mathrm{~km}$ ) could be classified as fair and poor respectively. These road conditions have highly significant effect on the cost of transportation of human and farm produce to market centres within the district. The economic implication of this is that while it costs an average of only Ghф 0.90 per tonne-kilometer to transport farm produce to the marker centres on the good roads, it costs an average of Gh $\varnothing 1.25$ per tonne-kilometer and Gh $\varnothing 1.43$ per tonne-kilometer to transport farm produce to the market centres on the fair and poor road network respectively within the district. This translates to an increase of approximately $39 \%$ and $59 \%$ respectively over and above transportation cost on the good roads. Similarly, the costs for passenger transportation on the districtroad network are an average of Gh $\varnothing 0.10$ per passenger-kilometer on those classified as good while it costs 
Table 3. Anova for data on passenger transportation cost (GHC per passenger-kilometer) on district road mix.

\begin{tabular}{cccccccc}
\hline Source of Variation & SS & df & MS & F & P-value & Fcrit $_{0.05}$ & Fcrit $_{0.01}$ \\
\hline a Road Condition & 0.045536 & 2 & 0.022768 & 15.82759 & 0.000108 & 3.554557 & 6.012904 \\
Error & 0.025893 & 18 & 0.001438 & & & \\
Total & 0.071429 & 20 & & & & \\
\hline
\end{tabular}

${ }^{\mathrm{a}} \mathrm{Road}$ condition-effect of road condition on passenger transportation cost is highly significant.

Table 4. ANOVA for data on agricultural produce transportation cost (GHC per tonne-kilometer) on district road mix.

\begin{tabular}{cccccc}
\hline Source of Variation & SS & df & MS & F & P-value \\
\hline a Road Condition & 1.087574 & 2 & 0.543787 & 1921.94 & $1.038 \mathrm{E}-21$ \\
Error & 0.005093 & 18 & 0.000283 & & \\
& & & & & \\
Total & 1.092667 & 20 & & & \\
\hline
\end{tabular}

${ }^{\mathrm{a}}$ Road condition-effect of road condition on agricultural produce transportation cost is highly significant.

Gh $\varnothing 0.140$ and Gh $\varnothing 0.21$ per passenger-kilometer on those classified as fair and poor respectively (translating to $40 \%$ and $110 \%$ increase respectively over and above cost of passenger transportation on good road). The implication of this is that farm commodity prices will be higher in those areas with fair and poor roads thus making it difficult, if not impossible, for farmers from those areas to be able to compete economically with those from those areas with good roads. In the final analysis, the farmers within the district will be suffering from high incidence of poverty and deprivation.

\section{Acknowledgements}

The authors wish to express their thanks to the Director and the entire management of the Department of Feeder Roads, Mampong Municipality of the Sekyere Central District of the Ashanti Region of Ghana for their technical advice, suggestions and comments during the data gathering stage of this work.

\section{REFERENCES}

[1] C. Gannon and Z. Liu, "Transporte: Infraestructurayservicios," Transport and Road Research Laboratory, Washington DC, 2001. http://www.worldbank.org

[2] G. Mendoza, "Compendio de Mercadeo de Productosagropecuarios," Ministry and Malagasy Public Works Ministry, 1991.

[3] ADB, "Proposed Loan to the Kingdom of Cambodia for the Greater Mekong Sub-Region: Cambodia Northwest Provincial Road Improvement Project," Report and Recommendation of the President to the Board of Directors, Manila Loan, 2009.
[4] NPC, "Ghana Population Stabilization Report," National Population Council, 2011.

[5] M. A. Cundill, J. L. Hine and P. A. K. Greening, "The Costs of Maintaining and Repairing Vehicles in Developing Countries," TRL Report No. 256, Transport Research Laboratory, Crowthorne, 1997.

[6] SCDA, "Status of the 2012 Budget Implementation," The Composite Budget of the Sekyere Central District Assembly for the 2013 Fiscal Year, Ashanti Region, 2013. www.ghanadistricts.com

[7] MOFA, "Latest Achievements in Sekyere Central District of Ashanti Region," Ministry of Food and Agriculture, Sekyere Central District, 2011.

Mofa.gov.gh/site/?page_id=877\#

[8] J. L. Hine, J. D. Riverson and N. E. A. Kwakye, “Accessibility, Transport Costs and Food Marketing in the AshantiRegion of Ghana," Transport and Road Research Laboratory, Crow Thorne, 1983.

[9] B. Ninnin, "Transport et Development A Madagascar," French Cooperation on Managing and Financing Rural Transport, Washington DC, 1997.

[10] J. L. Hine, "Transport and Marketing Priorities to Improve Food Security in Ghana and the Rest of Africa," International Symposium: Regional Food Security and Rural Infrastructure, Giessen, 3-5 May 1993, pp. 5-7.

[11] J. Dawson and I. Barwell, "Roads Are Not Enough: New Perspectives on Rural Transport Planning in Developing Countries," Intermediate Technology Publications, London, 1993.

[12] World Bank, “Attacking Poverty," World Development Report 2000-2001, Oxford University Press, Washington DC, 2001.

[13] P. Marion, "Regional and Rural Transport," Transport Research Knowledge Centre. D and G Publishers, 2010. 